\title{
STABILIZATION OF INSERTION ELECTRODES FOR LITHIUM BATTERIES
}

by

\author{
M. M. Thackeray, C. S. Johnson, A. J. Kahaian \\ K. D. Kepler and J. T. Vaughey \\ Electrochemical Technology Program \\ Chemical Technology Division \\ Argonne National Laboratory \\ Argonne, IL U.S.A.

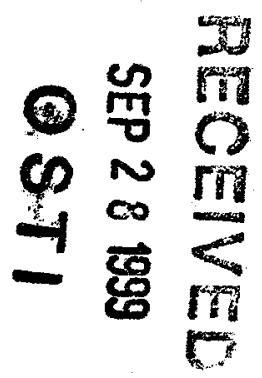

The submitted manuscript has been created by the University of Chicago as Operator of Argonne National Laboratory ("Argonne") under Contract No. W-31-109-ENG-38 with the U.S. Department of Energy. The U.S. Government retains for itself, and others acting on its behalf, a paid-up, nonexclusive, irrevocable worldwide license in said article to reproduce, prepare derivative works, distribute copies to the public, and perform publicly and display publicly, by or on behalf of the Government.

July 1998

To be presented at the 9th International Meeting on Lithium Batteries, Edinburgh, Scotland, United Kingdom, July 12-17, 1998 


\section{DISCLAIMER}

This report was prepared as an account of work sponsored by an agency of the United States Government. Neither the United States Government nor any agency thereof, nor any of their employees, make any warranty, express or implied, or assumes any legal liability or responsibility for the accuracy, completeness, or usefulness of any information, apparatus, product, or process disclosed, or represents that its use would not infringe privately owned rights. Reference herein to any specific commercial product, process, or service by trade name, trademark, manufacturer, or otherwise does not necessarily constitute or imply its endorsement, recommendation, or favoring by the United States Government or any agency thereof. The views and opinions of authors expressed herein do not necessarily state or reflect those of the United States Government or any agency thereof. 


\section{DISCLAIMER}

Portions of this document may be illegible in electronic image products. Images are produced from the best available original document. 


\title{
STABILIZATION OF INSERTION ELECTRODES FOR LITHIUM BATTERIES
}

M. M. Thackeray*, C. S. Johnson, A. J. Kahaian, K. D. Kepler and J. T. Vaughey

Electrochemical Technology Program, Chemical Technology Division

Argonne, Illinois, U.S.A.

and

Y. Shao-Horn and S. A. Hackney

Michigan Technological University

Houghton, Michigan, U.S.A.

Keywords: lithium battery, electrodes, structure, stability

\begin{abstract}
This paper discusses the techniques that are being employed to stabilize $\mathrm{LiMn}_{2} \mathrm{O}_{4}$ spinel and composite $\mathrm{Li}_{\mathrm{x}} \mathrm{MnO}_{2}$ positive electrodes. The critical role that spinel domains play in stabilizing these electrodes for operation at both $4 \mathrm{~V}$ and $3 \mathrm{~V}$ is highlighted. The concept of using an intermetallic electrode $\mathrm{MM}^{\prime}$ where $\mathrm{M}$ is an active alloying element and $M^{\prime}$ is an inactive element (or elements) is proposed as an alternative negative electrode (to carbon) for lithium-ion cells. An analogy to metal oxide insertion electrodes, such as $\mathrm{MnO}_{2}$, in which $\mathrm{Mn}$ is the electrochemically active ion and $\mathrm{O}$ is the inactive ion, is made. Performance data are given for the copper-tin electrode system, which includes the intermetallic phases eta- $\mathrm{Cu}_{6} \mathrm{Sn}_{5}$ and $\mathrm{Li}_{2} \mathrm{CuSn}$.
\end{abstract}

\section{Introduction}

To achieve a good cycle life in lithium-ion cells, both positive and negative insertion (host) electrodes must maintain their structural integrity when cycled over a wide compositional range. Host electrodes with cubic symmetry that can "breathe" isotropically during lithium insertion and extraction with minimal volume expansion provide structures that can withstand many discharge and charge cycles [1]. One of the best host structures is the lithium-titanium-oxide spinel $\mathrm{Li}_{4} \mathrm{Ti}_{5} \mathrm{O}_{12}$ that can accommodate

* Corresponding author, e-mail: thackeray@cmt.anl.gov: Tele: (630) 252-9184; FAX: (630) 252-4176. 
three lithium ions per formula unit without any significant lattice expansion [2]. It can be cycled hundreds of times without structural decay.

The cubic spinel $\mathrm{Li}\left[\mathrm{Mn}_{2}\right] \mathrm{O}_{4}$ is an electrode material of interest for both $3-\mathrm{V}$ and 4-V lithium batteries. For lithium insertion, i.e., over the range $1 \leq x \leq 2$ in $\mathrm{Li}_{x}\left[\mathrm{Mn}_{2}\right] \mathrm{O}_{4}$, the electrode operates at $3 \mathrm{~V}$ vs. metallic lithium [3], whereas lithium extraction occurs over the range $0<x<1$ at $4 \mathrm{~V}$ [4-6]. The reactions emphasize the stability of the stoichiometric $\mathrm{A}\left[\mathrm{B}_{2}\right] \mathrm{O}_{4}$ spinel composition: (1) lithium insertion causes an immediate first-order transition in which the tetrahedral-site lithium ions are displaced into neighboring octahedral sites to change the structure type, in a two-phase reaction, from spinel to a rock-salt phase $\mathrm{Li}_{2}\left[\mathrm{Mn}_{2}\right] \mathrm{O}_{4}$ [3]; (2) lithium extraction requires a high potential; and (3) the reaction creates a metastable, defect spinel structure with high chemical activity (reduction potential). The stability of the stoichiometric spinel composition $\mathrm{Li}\left[\mathrm{Mn}_{2}\right] \mathrm{O}_{4}$ is, perhaps, not surprising because the spinel structure occurs in nature as the prototypic mineral spinel, $\mathrm{Mg}\left[\mathrm{Al}_{2}\right] \mathrm{O}_{4}$, which is extremely stable and has gem-like qualities [7]. In the $\mathrm{Li}_{\mathrm{x}}\left[\mathrm{Mn}_{2}\right] \mathrm{O}_{4}$ system, the electrochemical reaction at $4 \mathrm{~V}$ provides good charge/discharge cycling behavior because the system remains cubic over the whole range $0<x<1$, whereas the reaction at $3 \mathrm{~V}$ induces a distortion in the lithiated spinel structure that reduces the crystallographic symmetry from cubic $(c / a=1)$ in $\mathrm{Li}\left[\mathrm{Mn}_{2}\right] \mathrm{O}_{4}$ to tetragonal symmetry $(c / a=1.16)$ in the rock-salt phase $\mathrm{Li}_{2}\left[\mathrm{Mn}_{2}\right] \mathrm{O}_{4}$. Such a severe change in the lattice parameter ratio is too large for the spinel electrode particles to maintain their structural integrity on cycling [1].

In practice, although $\mathrm{LiMn}_{2} \mathrm{O}_{4}$ spinel electrodes provide superior cycling behavior at $4 \mathrm{~V}$ than at $3 \mathrm{~V}$, the $4-\mathrm{V} \mathrm{Lix}_{\mathrm{x}}\left[\mathrm{Mn}_{2}\right] \mathrm{O}_{4}$ electrode $(0<\mathrm{x}<1)$ still loses capacity slowly at room temperature and more quickly at elevated temperature $\left(-50^{\circ} \mathrm{C}\right)[8]$. This loss in capacity has limited the use of $\mathrm{LiMn}_{2} \mathrm{O}_{4}$ electrodes in lithium-ion cells. Major efforts are being made to understand the reasons for the capacity loss at $4 \mathrm{~V}$ and to find ways to combat them. This paper discusses the role that $3 \mathrm{~V}$ spinel materials in the $\mathrm{Li}_{1+\mathrm{x}} \mathrm{Mn}_{2 \cdot \mathrm{x}} \mathrm{O}_{4}$ system $(0<x \leq 0.33)$ play, not only in stabilizing spinel electrodes at $4 \mathrm{~V}$, but also in stabilizing composite $\mathrm{Li}_{x} \mathrm{MnO}_{2}$ electrodes derived from $\gamma-\mathrm{MnO}_{2}$, layered-LiMnO${ }_{2}$ and orthorhombic- $\mathrm{LiMnO}_{2}$ materials. 
Also discussed in this paper is the concept of using an intermetallic compound $M M^{\prime}$, where $M$ is an active alloying element and $M^{\prime}$ is an inactive element (or elements) as alternative negative electrode material to lithiated carbon, $\mathrm{LiC}_{6}$; the latter electrodes can approach the potential of metallic lithium during charge and impose safety concerns on lithium-ion systems. The concept is an extension of the work that has been conducted on alloy systems, particularly that of Huggins and co-workers [9] and Besenhard and coworkers $[10,11]$. An analogy to $\mathrm{MnO}_{2}$, in which $\mathrm{Mn}$ is the electrochemically active ion and $O$ is the inactive ion, is made. Performance data are given for the copper-tin electrode system, which includes the intermetallic phases, eta- $\mathrm{Cu}_{6} \mathrm{Sn}_{5}$ and $\mathrm{Li}_{2} \mathrm{CuSn}$.

\section{Experimental}

The experimental methods that were used for this work have been presented elsewhere. Details for the work on the spinel-related systems can be found in references 12 and 13. The experimental details for the sample preparation and evaluation of the intermetallic systems $\mathrm{Cu}_{6} \mathrm{Sn}_{5+\delta}(\delta=0, \pm 1)$ and $\mathrm{Li}_{2} \mathrm{CuSn}$ can be found in references 14 and 15.

\section{Results and Discussion}

The Spinel Electrode $\mathrm{Li}_{x}\left[\mathrm{Mn}_{2}\right] \mathrm{O}_{4}(0<x<1)$

One of the major limitations of $\mathrm{Li}\left[\mathrm{Mn}_{2}\right] \mathrm{O}_{4}$ spinel electrodes for 4-V lithium-ion batteries is the capacity loss that occurs on cycling, for which several reasons have been given:

1. Solubility of the spinel electrode in the electrolyte, particularly under acidic conditions, according to the reaction first described by Hunter [16]:

$$
2 \mathrm{Mn}^{3+}{ }_{\text {(solid) }}-\ldots . .-\mathrm{Mn}^{4+}{ }_{\text {(solid) }}+\mathrm{Mn}^{2+}{ }_{\text {(solution) }}
$$


2. An instability of highly delithiated (charged) spinel structures, for example, by oxygen loss. Oxygen loss would increase the concentration of $\mathrm{Mn}^{3+}$ at the particle surface. It is conceivable, therefore, at $4 \mathrm{~V}$ that this could also lead to the disproportionation reaction given above and enhance the solubility of the spinel electrode.

3. Structural fatigue at the surface of spinel electrodes at the end of discharge of $4 \mathrm{~V}$ $\mathrm{Li} / \mathrm{Li}\left[\mathrm{Mn}_{2}\right] \mathrm{O}_{4}$ cells, resulting in the formation of the tetragonal phase $\mathrm{Li}_{2}\left[\mathrm{Mn}_{2}\right] \mathrm{O}_{4}$ $[12,17]$. This could occur either by overdischarge of $\mathrm{Li}\left[\mathrm{Mn}_{2}\right] \mathrm{O}_{4}$ particles under dynamic, non-equilibrium conditions or by self-discharge/soft shorts in the cell.

It has now been ascertained that solubility (point 1, above) is the major reason for the capacity fade. Solubility can be combatted by careful control of electrolyte $\mathrm{pH}$ or by protection of the surface of the spinel particles. These factors have been addressed elsewhere $[8,18-21]$.

Substituted spinels $\mathrm{Li}\left[\mathrm{Mn}_{2-\mathrm{x}} \mathrm{M}_{\mathrm{x}}\right] \mathrm{O}_{4}(\mathrm{M}=\mathrm{Cr}, \mathrm{Co}, \mathrm{Ni}, \mathrm{Cu})$ [22-25] that provide some capacity between 4.6 and $5.1 \mathrm{~V}$ offer the possibility of introducing an oxidation reaction within the spinel electrode, for example [25]:

$$
\mathrm{Cu}^{2+} \ldots \mathrm{Cu}^{3+}+\mathrm{e}^{-}
$$

to counter the evolution of oxygen (point 2 , above), i.e., the oxidation reaction

$$
\mathrm{O}^{2-}-\ldots 1 / 2 \mathrm{O}_{2}+\mathrm{e}^{-}
$$

This paper addresses, in more detail, point 3 above. In order to determine whether structural fatigue at the particle surface of spinel electrodes at the end of discharge could be a contributing factor to capacity loss, $\mathrm{Li} / \mathrm{Li}\left[\mathrm{Mn}_{2}\right] \mathrm{O}_{4}$ cells were cycled over various voltage ranges: 4.2-3.5 $\mathrm{V}, 4.2-3.3 \mathrm{~V}$, and 4.2-3.0 V [12]. Typical voltage profiles of $\mathrm{Li} / \mathrm{Li}\left[\mathrm{Mn}_{2}\right] \mathrm{O}_{4}$ cells cycled over the $4-\mathrm{V}$ region and $3-\mathrm{V}$ region at room temperature are given in Fig. 1a and 1b, respectively. Cells were cycled only ten times and were terminated at the end of discharge in an attempt to circumvent self-discharge/soft shorts. The cathodes were removed from the cells and subjected to analysis by electron diffraction and imaging. In each case, a small amount of the tetragonal phase $\mathrm{Li}_{2}\left[\mathrm{Mn}_{2}\right] \mathrm{O}_{4}$ was detected at the surface of some of the spinel particles (Fig. 2); the amount of 
tetragonal phase in the electrodes increased as the end voltage was lowered from 3.5 to $3.0 \mathrm{~V}$, as expected. Although an accurate quantitative analysis of the tetragonal phase in the electrode by transmission electron microscopy is not possible, the data showed that tetragonal phase in the total electrode amounted to only a fraction of a percent; such small concentrations are difficult to identify by conventional powder $X$-ray diffraction methods. Nevertheless, the data provide strong evidence that the tetragonal, lithiated spinel $\mathrm{Li}_{2}\left[\mathrm{Mn}_{2}\right] \mathrm{O}_{4}$ phase is produced at the surface of the electrode particles toward the end of discharge, under non-equilibrium conditions.

The stability to electrochemical cycling, particularly at room temperature, improved when the composition of the spinel electrode was modified to make it slightly lithium rich, i.e., within the system $\mathrm{Li}_{1+x} \mathrm{Mn}_{2-\mathrm{x}} \mathrm{O}_{4}$, typically with $\mathrm{x}=0.05$ [17]. In preliminary studies of $\mathrm{Li}_{1.05} \mathrm{Mn}_{1.95} \mathrm{O}_{4}$ electrodes, little evidence was found of a tetragonal phase on the surface of the particles, even when the electrodes were discharged to $2.89 \mathrm{~V}$, which is below the thermodynamic voltage for the onset of the tetragonal phase $(2.96 \mathrm{~V}$ [3]). This finding lends further support to the argument that $\mathrm{Li}_{1+x} \mathrm{Mn}_{2-\mathrm{x}} \mathrm{O}_{4}$ electrodes provide a cubic "buffer" zone that suppresses the onset of a Jahn-Teller distortion at the particle surface when the cells reach $3 \mathrm{~V}[12,17]$.

\section{Composite $\mathrm{Li}_{x} \mathrm{MnO}_{2}$ Electrodes}

The stability of the stoichiometric spinel structure is manifest by the fact that many lithium manganese oxide spinel compounds with lithium:manganese ratios varying between $1: 2$ and 1.25:1 (4:5) transform to a spinel structure either on heating or during electrochemical reactions. For example, the "Composite Dimensional Manganese Oxide" electrode ("CDMO" after Sanyo [26]) that is used for 3-V lithium batteries consists of domains of a lithiated gamma- $\mathrm{MnO}_{2}$ phase with orthorhombic symmetry and a cubic spinel phase (Fig. 3). "CDMO" is typically prepared by a reaction between electrolytically prepared $\mathrm{Y}-\mathrm{MnO}_{2}$ (EMD) and lithium hydroxide in a 7:3 molar ratio at temperatures between 250 and $420^{\circ} \mathrm{C}$ [26].

Orthorhombic-LiMnO $\mathrm{LiM}_{2}$ [27-29] and layered- $\mathrm{LiMnO}_{2}$ structures [30-32] are unstable to lithium extraction and electrochemical cycling; electron diffraction analyses 
of cycled electrodes have shown that they transform to spinel-type structures (Fig. 3). However, these electrode structures show superior cycling behavior when cycled over both the $4-\mathrm{V}$ and $3-\mathrm{V}$ plateaus, compared to the standard spinel $\mathrm{Li}\left[\mathrm{Mn}_{2}\right] \mathrm{O}_{4}[12,17]$ (compare Figs. 1 and 4). The $X$-ray and electron diffraction patterns show unequivocal evidence of a spinel phase in cycled electrodes $[13,27]$; lattice images of cycled electrodes indicate that the increased stability to cycling over a wide voltage window may be attributed to the presence of spinel domains that are embedded within a matrix of the residual orthorhombic- or layered- $\mathrm{LiMnO}_{2}$ structures (Fig. 5). Furthermore, it seems likely that the transformations of these $\mathrm{LiMnO}_{2}$ structures do not lead to spinel domains with the ideal $\left[\mathrm{Mn}_{2}\right] \mathrm{O}_{4}$ spinel framework, but rather with the $\left[\mathrm{Mn}_{2-\mathrm{x}} \mathrm{Li}_{\mathrm{x}}\right] \mathrm{O}_{4}$ framework of the spinel system $\mathrm{Li}_{1+\mathrm{x}} \mathrm{Mn}_{2-\mathrm{x}} \mathrm{O}_{4}(0<\mathrm{x} \leq 0.33)$ which displays superior cycling behavior at $3 \mathrm{~V}$ compared to $\mathrm{Li}\left[\mathrm{Mn}_{2}\right] \mathrm{O}_{4}$.

\section{Intermetallic Negative Electrodes $M M^{\prime}$}

Extensive research on metal oxide insertion electrodes has shown that good cycle life can only be achieved if the host structures maintain their structural integrity during repetitive discharge and charge with minimal change to the lattice parameters of the unit cell [1]. Alloy systems of $\mathrm{Li}_{\mathbf{x}} \mathrm{M}$ (for example, $\mathrm{M}=\mathrm{Al}, \mathrm{Si}, \mathrm{Sn}$ [9-11]) are attractive negative electrode materials for lithium cells because they offer a voltage above that of metallic lithium. This higher voltage makes it possible to overcome dendrite and safety problems associated with metallic lithium and lithiated carbon electrodes. However, a major limitation of these alloy systems is that they undergo phase transitions as the composition of the alloy changes. The concomitant large variations in lattice parameters and increase in unit cell volume impose a severe limitation on the ability of these electrode structures to provide a good cycle life. Therefore, we have investigated the possibility of introducing an electrochemically inactive element, $\mathrm{M}^{\prime}$, such as copper, which is also an excellent electronic conductor, to the alloying element $M$. This stabilizing component results in a composite electrode that would accommodate at least some of the damaging lattice expansion of a conventional $\mathrm{Li}_{\mathbf{x}} \mathrm{M}$ alloy system, such as $\mathrm{Li}_{x} \mathrm{Sn}$, during charge and discharge $[14,15]$. This concept is analogous on a macroscopic 
scale to a metal oxide insertion electrode such as $\mathrm{MnO}_{2}$, where $\mathrm{Mn}$ is the electrochemically active element (ion) and $\mathrm{O}$ the inactive element (ion). For our initial studies, we focused on the intermetallic systems $\mathrm{Cu}_{6} \mathrm{Sn}_{5+\delta}(\delta=0, \pm 1)$ and $\mathrm{Li}_{2} \mathrm{CuSn}$.

In an intermetallic system such as $\mathrm{Cu}_{6} \mathrm{Sn}_{5}$, the tin atoms are the electrochemically active component, and the copper atoms are the inactive component. Lithium insertion into the $\mathrm{Cu}_{6} \mathrm{Sn}_{5}$ structure is not possible because of the absence of an energetically favorable interstitial space; the structure is close packed with the copper atoms arranged in octahedral coordination and the tin atoms in trigonal prismatic coordination. Reaction with lithium, therefore, necessitates a displacement reaction and a break-up of the $\mathrm{Cu}_{6} \mathrm{Sn}_{5}$ structure; the lithium combines with the active tin to form a series of $\mathrm{Li}_{\mathrm{x}} \mathrm{Sn}$ compounds $(0<x \leq 4.4)$ within a residual copper matrix. In this reaction, it is envisaged that the divided copper atoms/particles that are produced on electrochemical cycling provide an electronically conducting matrix to contain the lithiated tin particles and to accommodate at least some of the damaging expansion/contraction of the $\mathrm{Li}_{\mathrm{x}} \mathrm{Sn}$ particles during discharge and charge. (Note that in $\mathrm{a} \mathrm{Li} / \mathrm{Cu}_{6} \mathrm{Sn}_{5}$ cell, discharge means the formation of a " $\mathrm{Li}_{\mathbf{x}} \mathrm{Cu}_{6} \mathrm{Sn}_{5}$ " composite electrode consisting of domains of lithiated tin and copper metal.) Optimum cycling conditions would be expected from such a composite $\mathrm{Cu} / \mathrm{Li}_{\mathbf{x}} \mathrm{Sn}$ material if it had an ideal microstructure in which the $\mathrm{Cu}$ and $\mathrm{Li}_{\mathrm{x}} \mathrm{Sn}$ particles were evenly distributed with sufficient porosity to accommodate the reacted lithium, thus allowing a minimal isotropic expansion of the overall electrode.

In the cubic structure of $\mathrm{Li}_{2} \mathrm{CuSn}$, the copper and tin atoms form an interlinked array of two face-centered-cubic lattices; the lithium atoms occupy the tetrahedral sites of the face-centered lattices to form fluorite-type configurations with each of the copper and tin arrays [14]. From a structural viewpoint, it is, therefore, conceivable that it might be possible to extract the lithium from the $\mathrm{Li}_{2} \mathrm{CuSn}$ structure. Note that complete extraction of lithium would result in a CuSn electrode with approximately the same Cu:Sn ratio as in the eta-phase $\mathrm{Cu}_{6} \mathrm{Sn}_{5}$, but with a different microstructure.

In $\mathrm{MnO}_{2}$, the ratio of inactive element to active element is $2: 1$, which is approximately twice the ratio in $\mathrm{Cu}_{6} \mathrm{Sn}_{5}$ (1.2:1). Therefore, it can be envisaged that increasing the inactive copper content in the intermetallic electrode would result in 
greater cycling stability; conversely, increasing the active tin content would be expected to reduce the cycling stability of the intermetallic electrode.

In order to test these hypotheses, $\mathrm{Li} / \mathrm{Cu}_{6} \mathrm{Sn}_{5+\delta}$ cells were evaluated at room temperature with electrodes having $\delta$ values of $-1\left(\mathrm{Cu}_{6} \mathrm{Sn}_{4}\right.$, copper-rich), $0\left(\mathrm{Cu}_{6} \mathrm{Sn}_{5}\right)$, and $+1\left(\mathrm{Cu}_{6} \mathrm{Sn}_{6}\right.$, tin-rich). The electrochemical behavior of a standard $\mathrm{Li} / \mathrm{Sn}$ cell was also determined, for comparison. The electrochemical profile of a $\mathrm{Li} / \mathrm{Cu}_{6} \mathrm{Sn}_{5}$ cell charged and discharged between 1.2 and $0.0 \mathrm{~V}$ is shown in Fig. 6; the profile is also characteristic of $\mathrm{Li} / \mathrm{Sn}, \mathrm{Li} / \mathrm{Cu}_{6} \mathrm{Sn}_{6}(\delta=1)$ and $\mathrm{Li} / \mathrm{Cu}_{6} \mathrm{Sn}_{4}(\delta=-1)$ cells. The profile shows an initial steep drop in voltage followed by a voltage plateau during discharge at approximately $400 \mathrm{mV}$; the latter process corresponds, predominantly, to the formation of $\mathrm{Li}_{7} \mathrm{Sn}_{3}$ within a copper matrix. It is believed that further reaction, with the cell voltage decreasing to $0 \mathrm{~V}$, occurs with the successive formation of the phases $\mathrm{Li}_{5} \mathrm{Sn}_{2}, \mathrm{Li}_{7} \mathrm{Sn}_{2}$ and $\mathrm{Li}_{22} \mathrm{Sn}_{5}$, as reported for $\mathrm{Li} / \mathrm{Sn}$ cells at $25{ }^{\circ} \mathrm{C}$ [9]. As can be deduced from the current interrupts in Fig. 6 that occur every hour during discharge and charge, the impedance of the cell improves dramatically after the first discharge. This improvement can be attributed to the establishment of better contact between electrolyte and active material and between individual particles during the early conditioning of the cells.

For the intermetallic phase, $\mathrm{Li}_{2} \mathrm{CuSn}$ lithium is extracted with a steadily increasing voltage to a cut-off potential of $1.2 \mathrm{~V}$ [14]; on the subsequent discharge, the electrode does not show the characteristic plateau at $400 \mathrm{mV}$, but rather shows a continuous decrease in voltage to $0 \mathrm{~V}$.

As shown in Table 1, the addition of copper to a tin electrode decreases the theoretical capacity of the tin electrode. Table 1 also gives the theoretical capacity of $\mathrm{Li}_{2} \mathrm{CuSn}$ in terms of its ideal fully delithiated composition CuSn; it has the same composition as $\mathrm{Cu}_{6} \mathrm{Sn}_{6}(\delta=1)$. (Complete removal of lithium from $\mathrm{Li}_{2} \mathrm{CuSn}$ corresponds to a capacity of $273 \mathrm{mAh} / \mathrm{g}$.) Compared to the theoretical capacity of $372 \mathrm{mAh} / \mathrm{g}$ for $\mathrm{LiC}_{6}$, the gravimetric capacity of the copper-tin electrodes, when lithiated to a 1:1 $\mathrm{Li}: \mathrm{Sn}$ ratio, is too small for it to be of practical interest for lithium-ion cells. However, for compositions reaching higher lithium content ( $\mathrm{Li}_{7} \mathrm{Sn}_{3}$ to $\mathrm{Li}_{4.4} \mathrm{Sn}$ ), as shown in Table 1, the available capacity becomes more attractive. Because lithium-metal alloy systems have 
high crystallographic densities, they provide higher volumetric capacities than lithiated carbon, $\mathrm{LiC}_{6}(\sim 750 \mathrm{mAh} / \mathrm{ml})$. For example, $\mathrm{Cu}_{6} \mathrm{Sn}_{5}$ has a density of $8.28 \mathrm{~g} / \mathrm{ml}$; it will, therefore, provide a volumetric capacity of approximately $2450 \mathrm{mAh} / \mathrm{ml}$ when discharged to a $\mathrm{Li}_{7} \mathrm{Sn}_{3}$ composition $\left(\mathrm{Li}_{11.67} \mathrm{Cu}_{6} \mathrm{Sn}_{5}\right)$.

Table 1. Relative Capacities of $\mathrm{Sn}, \mathrm{CuSn}$, and $\mathrm{Cu}_{6} \mathrm{Sn}_{5+\delta}(\delta=0, \pm 1)$

\begin{tabular}{|c|c|c|c|c|}
\hline Electrode & $\begin{array}{l}\delta \text { in } \\
\mathrm{Cu}_{6} \mathrm{Sn}_{5+\delta}\end{array}$ & $\begin{array}{l}\text { Theor. Capacity* } \\
\text { (mAh/g) to LiSn } \\
\text { Composition }\end{array}$ & $\begin{array}{l}\text { Theor. Capacity* } \\
\text { (mAh/g) to } \mathrm{Li}_{7} \mathrm{Sn}_{3} \\
\text { Composition }\end{array}$ & $\begin{array}{l}\text { Theor. Capacity* } \\
\text { (mAh/g) to } \mathrm{Li}_{4.4} \mathrm{Sn} \\
\text { composition }\end{array}$ \\
\hline $\mathrm{Sn}$ & - & 226 & 527 & 994 \\
\hline $\mathrm{Cu}_{6} \mathrm{Sn}_{6}$ & +1 & 147 & 343 & 647 \\
\hline $\mathrm{Cu}_{6} \mathrm{Sn}_{5}$ & 0 & 137 & 320 & 604 \\
\hline $\mathrm{Cu}_{6} \mathrm{Sn}_{4}$ & -1 & 125 & 292 & 551 \\
\hline CuSn** & $(+1)$ & 147 & 343 & 647 \\
\hline
\end{tabular}

If $\mathrm{Li} / \mathrm{Sn}$ and $\mathrm{Li} / \mathrm{Cu}_{6} \mathrm{Sn}_{5+\delta}$ cells $(\delta=0, \pm 1)$ are cycled over the range 1.2 to $0 \mathrm{~V}$, the pure tin electrode provides a significantly higher capacity on the initial discharge ( 670 $\mathrm{mAh} / \mathrm{g}$ ) than copper-tin electrodes [14]; the capacity of the pure tin electrode decreases rapidly on cycling, dropping to $\sim 115 \mathrm{mAh} / \mathrm{g}$ after 10 cycles. By contrast, the copper-tin electrodes $\mathrm{Cu}_{6} \mathrm{Sn}_{5+\delta}(\delta=0, \pm 1)$ show lower capacity (as expected) but improved stability to electrochemical cycling. The $\mathrm{Cu}_{6} \mathrm{Sn}_{6}, \mathrm{Cu}_{6} \mathrm{Sn}_{5}$, and $\mathrm{Cu}_{6} \mathrm{Sn}_{4}$ electrodes deliver 350, 340 and $440 \mathrm{mAh} / \mathrm{g}$ on the initial discharge, and 180,175 and $280 \mathrm{mAh} / \mathrm{g}$ after $10 \mathrm{cycles}$, respectively [14]. The copper-rich electrode $\mathrm{Cu}_{6} \mathrm{Sn}_{4}$ shows the greatest cycling stability, in agreement with the hypothesis that higher concentrations of inactive component in composite copper-tin electrodes would enhance electrochemical rechargeability. Reducing the voltage range to 1.2-0.2 V improves the cycling stability of the copper-tin electrodes even further (Fig. 7); in this case, excellent cycling stability is achieved but at the expense of some capacity. For example, over this voltage range, the $\mathrm{Cu}_{6} \mathrm{Sn}_{4}$ electrode delivers an initial capacity of $165 \mathrm{mAh} / \mathrm{g}$, which increases on cycling as the electrode is conditioned; it delivers a steady $190 \mathrm{mAh} / \mathrm{g}$ after 10 cycles. 


\section{Conclusions}

This paper has stressed the importance of structural features that are required for designing positive and negative insertion electrodes for lithium-ion cells. The following points summarize the major features of the discussion:

1. Stoichiometric ( $3 \mathrm{~V}$ ) lithium-manganese-oxide spinel compounds are very stable materials; the spinel structure is destabilized by lithium insertion and extraction.

2. The $\mathrm{Li}_{1+\mathrm{x}} \mathrm{Mn}_{2-\mathrm{x}} \mathrm{O}_{4}(3 \mathrm{~V})$ spinels play an important role in stabilizing the surface of $4 \mathrm{~V}$ $\mathrm{Li}_{\mathrm{x}}\left[\mathrm{Mn}_{2}\right] \mathrm{O}_{4}$ spinel electrodes and composite $\mathrm{Li}_{x} \mathrm{MnO}_{2}$ structures.

3. Intermetallic compounds $\mathbf{M M}^{\prime}$, where $\mathrm{M}$ is an alloying element and $\mathrm{M}^{\prime}$ is an inactive element with good electrical properties, such as $\mathrm{Cu}_{6} \mathrm{Sn}_{5}$, show promise as negative electrodes for lithium cells and, in particular, for controlling the volume expansion of conventional $\mathrm{Li}_{\mathbf{x}} \mathrm{M}$ alloy systems, such as $\mathrm{Li}_{\mathbf{x}} \mathrm{Sn}$.

4. Control of microstructural properties is critical to achieving good electrochemical cycling in positive and negative electrode materials for lithium-ion cells.

\section{Acknowledgment}

Support for the work presented in this paper from the U.S. Department of Energy Advanced Battery Program, Chemical Sciences Division, Office of Basic Energy Sciences under contract W-31-109-ENG-38 is gratefully acknowledged. 


\section{References}

1. M. M. Thackeray, J. Electrochem. Soc., 142, 2558 (1995).

2. K. M. Colbow, J. R. Dahn and R. R. Haering, J. Power Sources, 26, 397-402 (1989).

3. M. M. Thackeray, W. I. F. David, P. G. Bruce and J. B. Goodenough, Mater. Res. Bull., 18, 461 (1983).

4. M. M. Thackeray, P. J. Johnson, L. A. de Picciotto, P. G. Bruce and J. B. Goodenough, Mat. Res. Bull., 19, 179-187 (1984).

5. T. Ohzuku, M. Kitagawa and T. Hirai, J. Electrochem. Soc., 137, 769 (1990).

6. J. M. Tarascon, E. Wang, F. K. Shokoohi, W. R. McKinnon and S. Colson, J. Electrochem. Soc., 138, 2859 (1991).

7. R. W. Hughes, Ruby and Sapphire, RWH Publishing, Boulder, Colorado (1997).

8. G. G. Amatucci, A. Blyr, C. Sigala, P. Alfonse and J. M. Tarascon, Solid State Ionics, 104, 13 (1997).

9. J. Wang, I. D. Raistrick, and R. A. Huggins, J. Electrochem. Soc., 133, 457 (1986).

10. J. O. Besenhard, P. Komenda, A. Paxinos, E. Wudy, and M. Josowicz, Solid State Ionics, 18-19, 823 (1986)

11. J. O. Besenhard, J. Yang, and M. Winter, J. Power Sources, 68, 87 (1997).

12. M. M. Thackeray, Y. Shao-Horn, A. J. Kahaian, K. D. Kepler, E. Skinner, J. T. Vaughey and S. A Hackney, Electrochemical and Solid State Letters, 1, 7-9 (1998).

13. Y. Shao-Horn, S. A. Hackney, A. R. Armstrong, P. G. Bruce, R. Gitzendanner, C. S. Johnson and M. M. Thackeray, J. Electrochem. Soc., (1998). In press.

14. K. D. Kepler, J. T. Vaughey and M. M. Thackeray, J. Electrochem. Soc., (1998). Submitted.

15. K. D. Kepler, J. T. Vaughey and M. M. Thackeray, J. Power Sources, (1998). Submitted.

16. J. C. Hunter, J. Solid State Chem., 39, 142-147 (1981).

17. R. J Gummow, A. de Kock and M. M. Thackeray, Solid State Ionics, 69, 59-67 (1994). 
18. G. G. Amatucci, C. N. Schmutz, A. Blyr, C. Sigala, A. S. Gozdz, D. Larcher and J. M. Tarascon, J. Power Sources, 69, 11-25 (1997).

19. Y. Xia, Y. Zhou and M. Yoshio, J. Electrochem. Soc., 144, 2593-2600 (1997).

20. D. H. Jang and S. M. Oh, J. Electrochem. Soc., 144, 3342-3348 (1997).

21. A. Blyr, C. Sigala, G. G. Amatucci, D. Guyomard, Y. Chabres, and J. M. Tarascon, J. Electrochem. Soc. 145, 194-209 (1998).

22. C. Sigala, D. Guyomard, A. Verbaere, Y. Piffard, and M Toumoux, Solid State Ionics, 81, 167 (1995).

23. H. Kawai, M. Nagata, H. Tukamoto and A. R. West, J. Mater. Chem., 8, 837 (1998).

24. Q. Zheng, A. Bonakdarpour, M. Zhang, Y. Gao, and J. R. Dahn, J. Electrochem. Soc., 144, 205 (1997).

25. Y. Ein-Eli, W. F. Howard, S. H. Lu, S. Mukerjee, J. McBreen, J. T. Vaughey, and M. M. Thackeray, J. Electrochem. Soc., 145, 1238 (1998).

26. T. Nohma, T. Saito, N. Furukawa and H. Ikeda, J. Power Sources, 26, 389-396 (1989).

27. R. J. Gummow and M. M. Thackeray, J. Electrochem. Soc., 141, 1178-1182 (1994).

28. I. Koetschau, M. N. Richard, J. R. Dahn, J. B. Soupart and J. C. Rousche, J. Electrochem. Soc., 142, 2906-2910 (1995).

29. I. J. Davidson, R. S. McMillan, J. J. Murray and J. E. Greedan, J. Power Sources, 54, 232-235 (1995).

30. A. R. Armstrong and P.G. Bruce, Nature, 381, 499-500 (1996).

31. F. Capitaine, P. Gravereau and C. Delmas, Solid State Ionics, 89, 197-202 (1996).

32. G. Vitins and K. West, J. Electrochem. Soc., 144, 2587-2592 (1997). 


\section{Captions to Figures}

1. Voltage profiles of $\mathrm{Li} / \mathrm{Li}\left[\mathrm{Mn}_{2}\right] \mathrm{O}_{4}$ cells showing the superior capacity retention at (a) $4 \mathrm{~V}$ compared to (b) $3 \mathrm{~V}$.

2. Electron diffraction patterns of (a) a parent $\mathrm{Li}\left[\mathrm{Mn}_{2}\right] \mathrm{O}_{4}$ crystal and (b) a tetragonal crystal on the surface of an electrochemically cycled spinel electrode, discharged between 4.2 and $3.3 \mathrm{~V}$ ([001] zone axes).

3. Electron diffraction patterns of (a) a cubic spinel crystal ([001] zone axis) and (b) an orthorhombic lithiated- $\gamma-\mathrm{MnO}_{2}$ crystal ([1-20] zone axis) in a "CDMO" product synthesized at $250^{\circ} \mathrm{C}$.

4. The voltage profiles of lithium cells with (a) layered- $\mathrm{LiMnO}_{2}$ [13] and (b) orthorhombic-LiMnO $\mathrm{L}_{2}$ [27] electrodes.

5. The microstructure of $\mathrm{Li}_{0.5} \mathrm{MnO}_{2}$ derived from a layered-LiMnO $\mathrm{L}_{2}$ electrode showing microdomains of spinel embedded within a residual layered- $\mathrm{Li}_{\mathrm{x}} \mathrm{MnO}_{2}$ structure.

6. A typical charge/discharge profile of a $\mathrm{Li} / \mathrm{Cu}_{6} \mathrm{Sn}_{5}$ cell.

7. Capacity vs. cycle number for $\mathrm{Li} / \mathrm{Sn}$ and $\mathrm{Li} / \mathrm{Cu}_{6} \mathrm{Sn}_{5+\delta}(\delta=0, \pm 1)$ cells. 

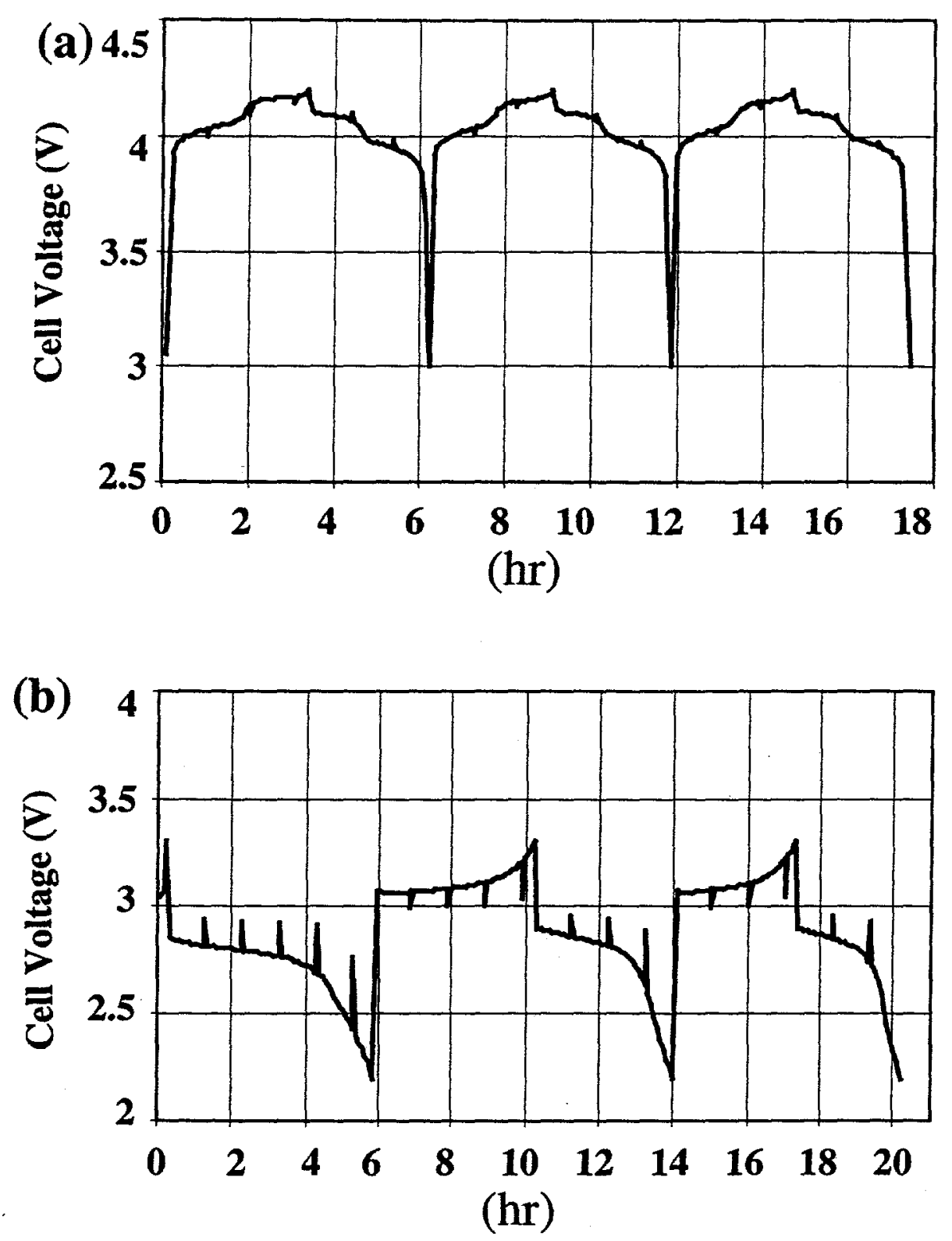

Figure 1 


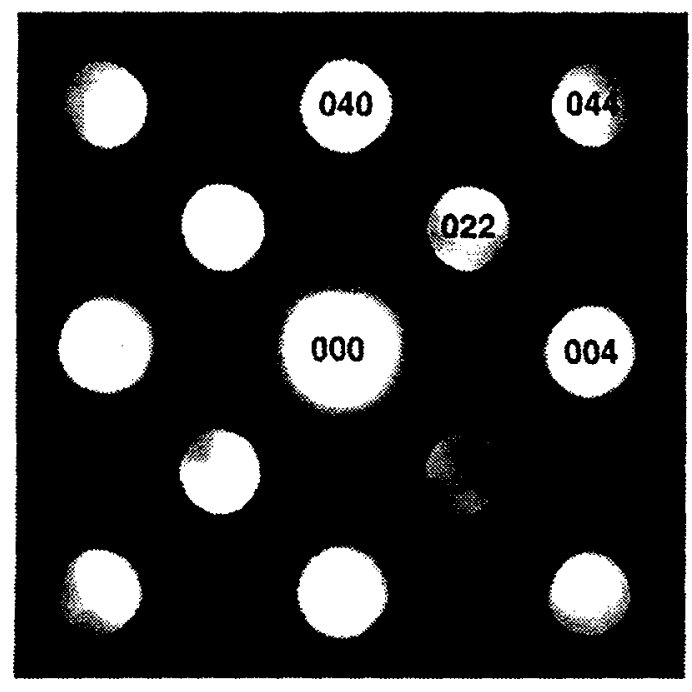

(a)

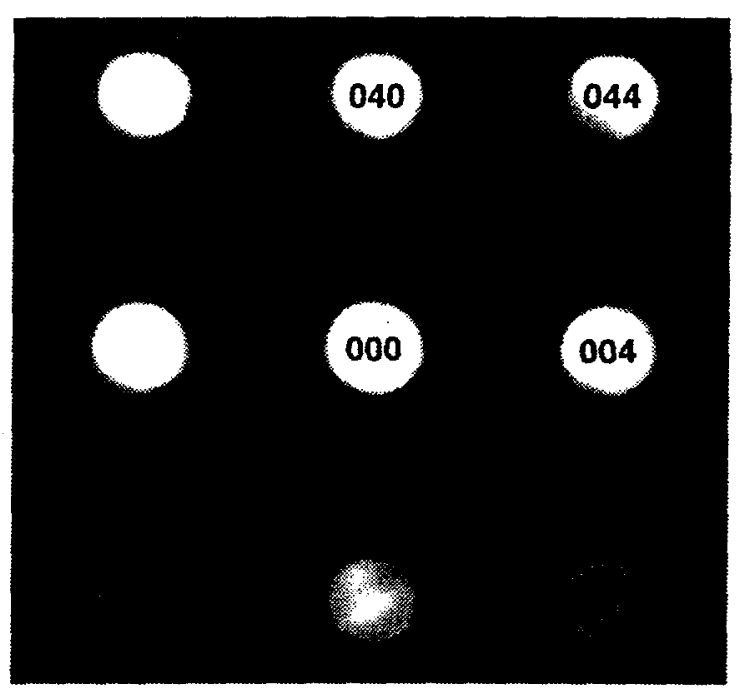

(b)

Figure 2 


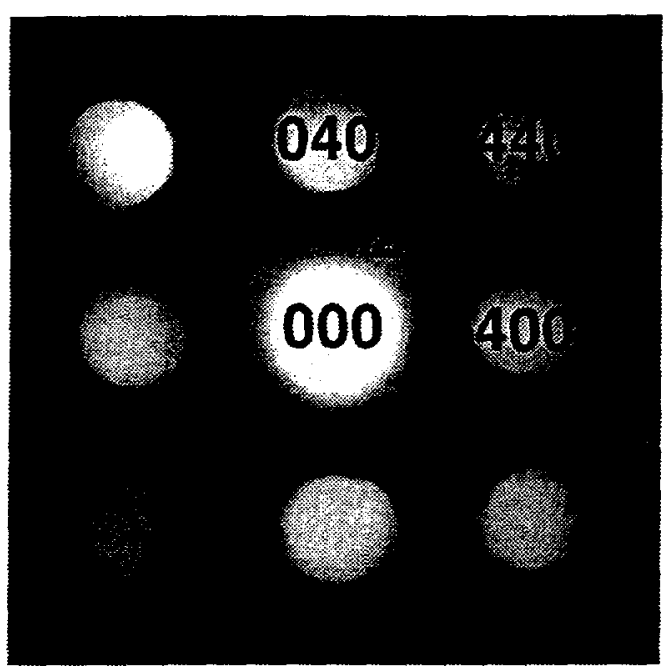

(a)

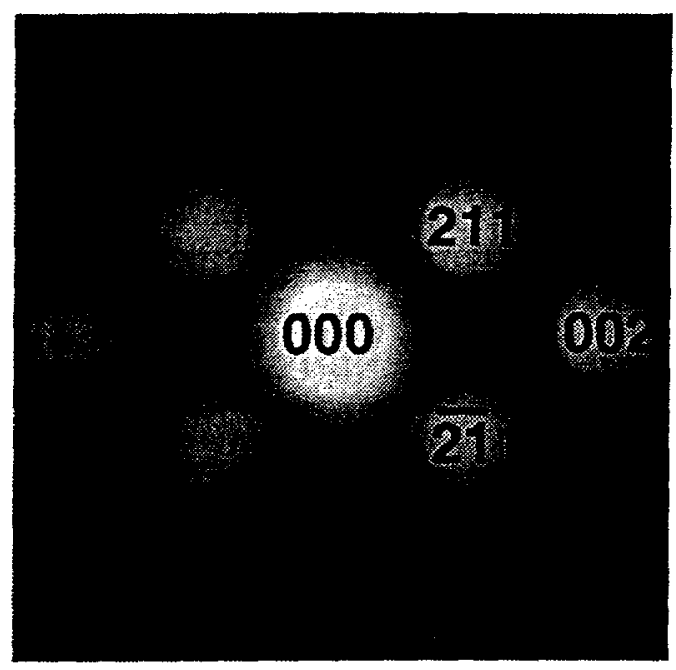

(b)

Figure 3 


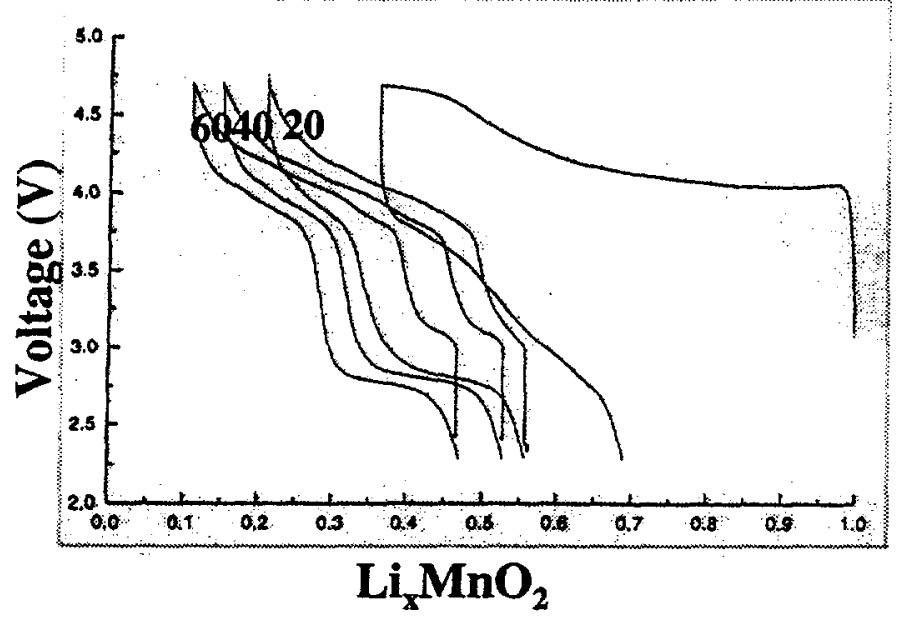

(a)

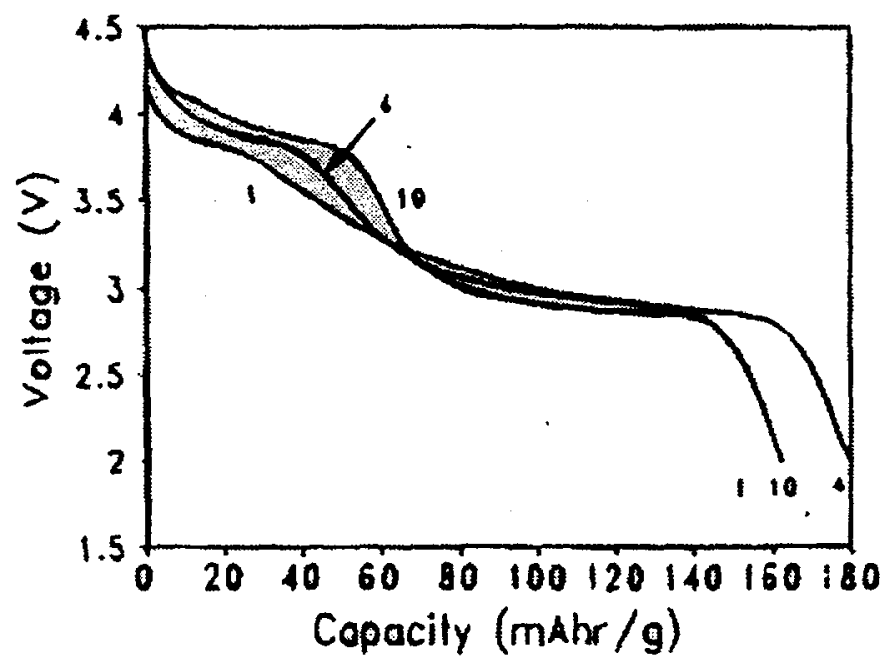

(b)

Figure 4 


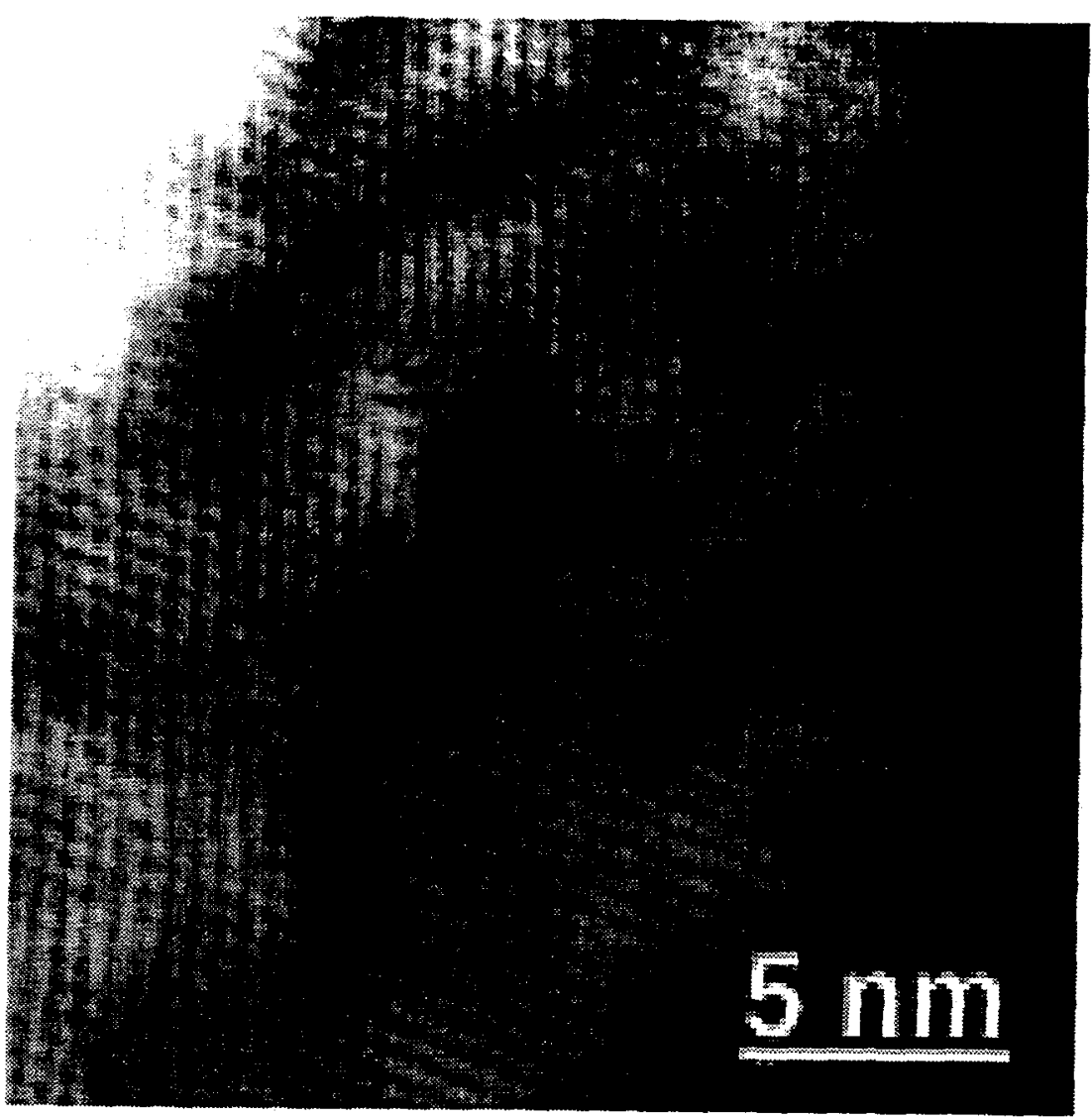

Figure 5 


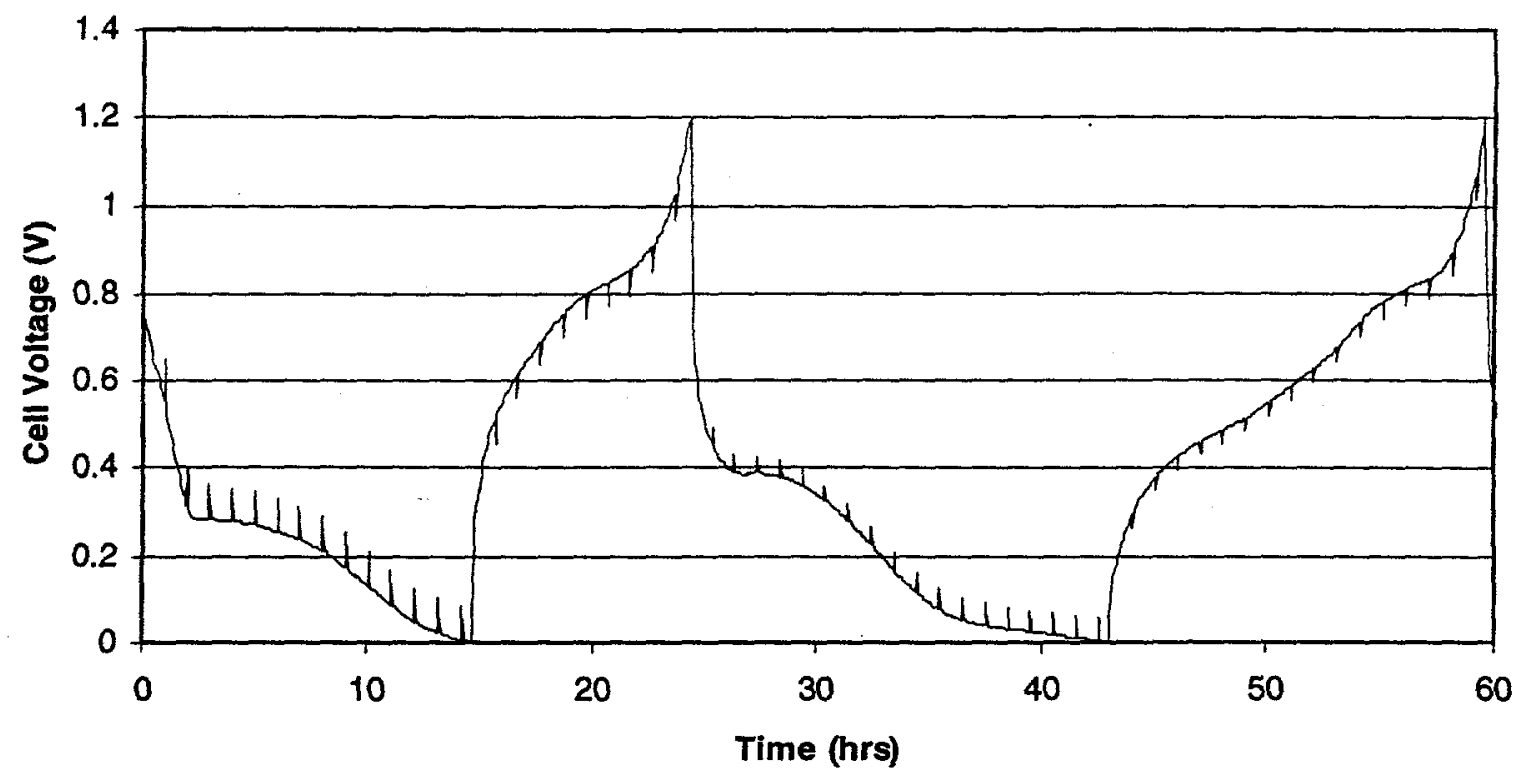

Figure 6 


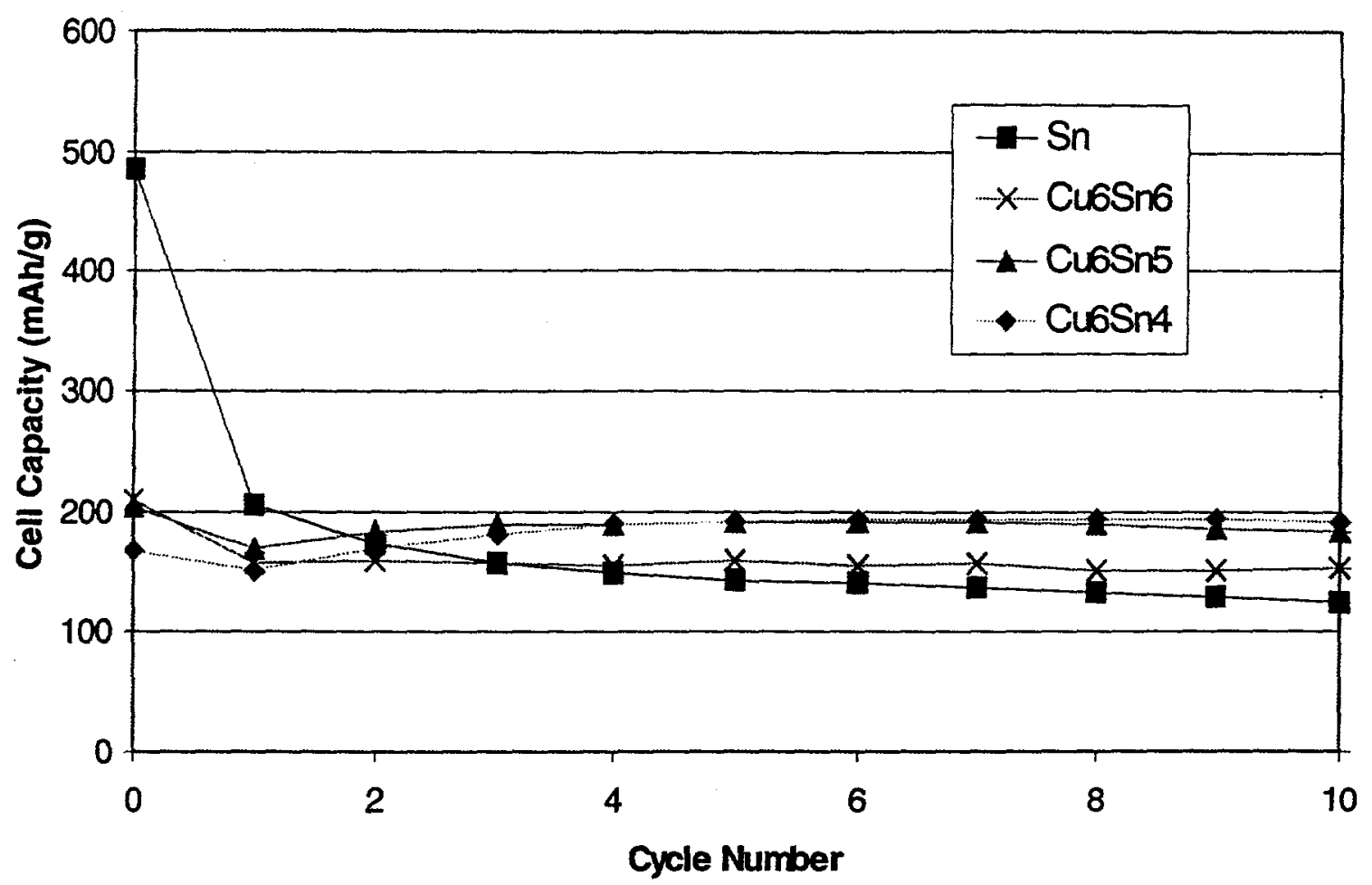

Figure 7 